Indonesian Journal for Social Responsibility (IJSR) Vol. 3, No. 01, (2021), hal. 47- 64

\title{
PROGRAM PELATIHAN MOTIVASI USAHA, SUMBER MODAL USAHA DAN PENYUSUNAN LAPORAN KEUANGAN BAGI PENYANDANG DISABILITAS DI WILAYAH KECAMATAN SUKAJADI KOTA BANDUNG
}

\author{
Dudi Rudianto ${ }^{1^{*}}$, Monica Weni Pratiwi ${ }^{2}$, Siti Zubaidah Chaidir ${ }^{3}$, Nurusyifa ${ }^{2}$ \\ ${ }^{1}$ Program Studi Magister Manajemen, ${ }^{2}$ Program Studi Akuntansi, ${ }^{3}$ Program Studi Manajemen, \\ Fakultas Ekonomi dan Ilmu Sosial, Universitas Bakrie, Indonesia \\ E-mail: dudi.rudianto@bakrie.ac.id*,monica.wenipratiwi@bakrie.ac.id, sitizc9@gmail.com,nrsy.syifa1224@gmail.com
}

Received: April 29, 2021 / Revised: June 10, 2021 / Accepted: June 25, 2021

DOI: https://doi.org/10.36782/ijsr.v3i1.83

\begin{abstract}
ABSTRAK
Penanganan bagi penyandang disabilitas memerlukan bantuan dan partisipasi masyarakat secara luas agar mereka bisa hidup mandiri dan merasa "normal" diantara sesama anggota masyarakat lainnya. Upaya tersebut dilakukan melalui program pelatihan motivasi usaha, rencana bisnis, sumber modal usaha dan penyusunan laporan keuangan yang difasilitasi oleh Lembaga Pengabdian kepada Masyarakat (LPkM) Universitas Bakrie bagi penyandang disabilitas di wilayah Kecamatan Sukajadi Kota Bandung. Program pelatihan dilaksanakan secara offline selama 2 hari tanggal 15 - 16 Maret 2021 di Aula Kecamatan Sukajadi Kota Bandung. Peserta yang mengikuti pelatihan berjumlah 18 orang penyandang disabilitas, terdiri dari 9 orang cacat tubuh, 7 orang tuna netra dan 2 orang tuna rungu. Materi pelatihannya terdiri dari motivasi usaha, rencana bisnis, sumber modal usaha dan penyusunan laporan keuangan sederhana. Setelah mengikuti program pelatihan ini, seluruh peserta merasakan manfaat yang diperoleh, hasil ini ditunjukkan oleh nilai post-test yang lebih tinggi dibandingkan nilai pre-test untuk semua materi pelatihan, masing-masing meningkat $40 \%$ untuk materi motivasi usaha, $30 \%$ untuk materi rencana bisnis, $60 \%$ untuk materi sumber modal usaha dan $40 \%$ untuk materi penyusunan laporan keuangan. Demikian juga meningkatnya keinginan para peserta untuk memperoleh tindak lanjut dari program pelatihan dalam bentuk pendampingan untuk menjadi pengusaha yang sebenarnya. Keinginan ini ditunjukkan oleh video testimoni dari wakil peserta dan aktifnya para peserta pada WhatsApp Group yang anggotanya adalah sesama peserta pelatihan dan semua narasumber, sebagai sarana diskusi dan informasi. Salah satu hasil implementasi dari kegiatan pelatihan ini, salah satu peserta pelatihan ikut bergabung dengan UMKM usaha konveksi untuk mengikuti pameran yang diadakan di Bandung Trade Mall.
\end{abstract}

Kata kunci: Laporan Keuangan, Modal Usaha, Motivasi, Pengusaha, Rencana Bisnis.

\section{ABSTRACT}

Handling for persons with disabilities requires assistance and broad community participation so that they can live independently and feel "normal" among other members of the community. These efforts are carried out through business motivation training programs, business plans, sources of business capital and preparation of financial reports facilitated by the Bakrie University Community Service Institute (LPKM) for people with disabilities in the Sukajadi District, 
Bandung City. The training program was carried out offline for 2 days from 15-16 March 2021 at the Sukajadi District Hall, Bandung City. The participants who attended the training were 18 people with disabilities, consisting of 9 people with physical disabilities, 7 people who were blind and 2 people who were deaf. The training materials consist of business motivation, business plans, sources of venture capital and the preparation of simple financial reports. After participating in this training program, all participants feel the benefits obtained, this result is shown by the post-test scores which are higher than the pre-test scores for all training materials, each increasing 40\% for business motivation materials, 30\% for planning materials business, $60 \%$ for business capital sources and $40 \%$ for financial statement preparation materials. Likewise, the participants' increased desire to receive follow-up from the training program in the form of mentoring to become real entrepreneurs. This desire is shown by video testimonials from participant representatives and the active participation of participants in the WhatsApp Group whose members are fellow trainees and all resource persons, as a means of discussion and information. One of the results of the implementation of this training activity, one of the training participants joined the MSME convection business to take part in the exhibition held at the Bandung Trade Mall.

Keywords: Business Plan, Entrepreneur, Financial Statements, Motivation, Venture Capital.

\section{PENDAHULUAN}

Kota Bandung sebagai ibukota Provinsi Jawa Barat, provinsi dengan jumlah penduduk terbanyak di Indonesia (Badan Pusat Statistik, 2020) memiliki jumlah penyandang disabilitas yang cukup banyak terutama di Kecamatan Sukajadi. Kecamatan Sukajadi merupakan daerah dengan jumlah penyandang disabilitas yang terbesar di Kota Bandung yaitu sebanyak 396 orang (Portal Data Kota Bandung, 2019). Dimana dari jumlah tersebut didominasi oleh cacat tubuh sebesar 29\%, buta (tuna netra) 22\% serta bisu dan tuli masing-masing 16\%. Penyandang disabilitas (cacat tubuh) pada dasarnya memiliki kemampuan dan potensi yang dapat dikembangkan agar dapat mandiri. Untuk dapat mandiri penyandang cacat memerlukan rehabilitasi sosial melalui peningkatan kepedulian masyarakat kepada penyandang disabilitas, diantaranya penyediaan aksesibilitas di setiap ruang publik dan tempat kerja, pemberian pelayanan sosial mengacu pada kebutuhan penyandang disabilitas. (Hikmawati \& Rusmiyati, 2011). Kemandirian disabilitas merujuk pada keadaan saat mereka dapat melakukan segala aktivitas keseharian untuk memenuhi segala kebutuhan dan keinginannya sendiri tanpa mengharapkan bantuan dari orang lain (Akurat.co., 2019). Kemandirian ini dicirikan oleh sikap tidak tergantung terhadap orang lain, memiliki kepercayaan diri, berperilaku disiplin, tekun dan gigih, memiliki rasa tanggung jawab, kreatif, mampu mengambil keputusan, melakukan kontrol diri, dan tidak mudah putus asa (Keumala, 2016).

Kemandirian disabilitas biasanya akan mudah dicapai apabila mereka berdaya baik secara ekonomi dan sosial. Oleh karena itu, 
pemberdayaan ekonomi dan sosial merupakan kunci mencapai kemandirian para disabilitas (Dhairyya \& Herawati, 2019). Perbedaan jenis disabilitas akan menentukan jenis keterampilan apa yang bisa dilatih kepada penyandang disabilitas dalam membangun usahanya. Masalah permodalan usaha seringkali menjadi suatu kendala dalam memulai suatu usaha termasuk upaya pengembangannya. Faktor itulah yang melatarbelakangi perlunya diadakan suatu kegiatan Pengabdian kepada Masyarakat (PkM) untuk mengembangkan motivasi dan potensi bagi para penyandang disabilitas dalam berwirausaha yang sesuai dengan jenis disabilitasnya di Kecamatan Sukajadi di Kota Bandung serta upaya untuk pengembangan usaha bagi penyandang disabilitas yang sudah punya usaha termasuk informasi mengenai upaya-upaya untuk memperoleh modal usaha.

Kegiatan pengabdian kepada masyarakat (PkM) ini bertujuan untuk memberikan pelatihan tentang motivasi usaha, penyusunan rencana bisnis, sumber modal usaha dan penyusunan laporan keuangan bagi penyandang disabilitas di wilayah Kecamatan Sukajadi Kota Bandung. Adapun manfaat dari program pelatihan ini bagi penyandang disabilitas, diharapkan dapat menumbuhkan dan meningkatkan motivasi usaha dalam berwirausaha sesuai kemampuan dan jenis disabilitasnya sehingga nantinya mereka menjadi pribadi yang tangguh dan mandiri baik secara sosial maupun secara ekonomi serta memperoleh informasi mengenai beberapa pilihan sumber modal usaha yang bisa digunakan.

\section{TINJAUAN PUSTAKA}

Menurut Undang-Undang No. 8 Tahun 2016, Penyandang Disabilitas adalah setiap orang yang mengalami keterbatasan fisik, intelektual, mental, dan/atau sensorik dalam jangka waktu lama yang dalam berinteraksi dengan lingkungan dapat mengalami hambatan dan kesulitan untuk berpartisipasi secara penuh dan efektif dengan warga negara lainnya berdasarkan kesamaan hak. Menurut pasal 4 Undang-Undang No. 8 Tahun 2016, dikatakan bahwa ragam atau jenis Penyandang Disabilitas meliputi 4 (empat) jenis, yaitu:
a. Penyandang Disabilitas fisik,
b. Penyandang Disabilitas intelektual,
c. Penyandang Disabilitas mental, dan
d. Penyandang Disabilitas sensorik.

Penyandang Disabilitas memiliki hak atas pekerjaan, kewirausahaan dan koperasi, yang meliputi hak untuk :
a. memperoleh
pekerjaan
yang
diselenggarakan oleh Pemerintah, Pemerintah Daerah, atau swasta tanpa Diskriminasi;

b. memperoleh upah yang sama dengan tenaga kerja yang bukan Penyandang Disabilitas dalam jenis pekerjaan dan tanggung jawab yang sama; 
c. memperoleh Akomodasi yang Layak dalam pekerjaan;

d. tidak diberhentikan karena alasan disabilitas;

e. mendapatkan program kembali bekerja;

f. penempatan kerja yang adil, proporsional, dan bermartabat;

g. memperoleh kesempatan dalam mengembangkan jenjang karier serta segala hak normatif yang melekat di dalamnya; dan

h. memajukan usaha, memiliki pekerjaan sendiri, wiraswasta, pengembangan koperasi, dan memulai usaha sendiri.

Motivasi adalah serangkaian sikap dan nilainilai yang mempengaruhi individu untuk mencapai hal yang spesifik sesuai dengan tujuan individu. Sikap dan nilai tersebut merupakan suatu kekuatan untuk mendorong individu bertingkah laku dalam mencapai tujuan. Dorongan tersebut terdiri dari dua komponen, yaitu: arah perilaku kerja (kerja untuk mencapai tujuan), dan kekuatan perilaku (sebagai kuat usaha individu dalam bekerja). Motivasi meliputi perasaan unik, pikiran dan pengalaman masa lalu yang merupakan bagian dari hubungan internal dan eksternal perusahaan. Motivasi sering kali diartikan pula sebagai faktor pendorong perilaku seseorang.

Menurut Robbins dan Timothy (2008), motivasi sebagai proses yang menjelaskan intensitas, arah dan ketekunan seseorang individu untuk mencapai tujuan. Berdasarkan pendapat tersebut dapat disimpulkan bahwa; (1) Motivasi kerja merupakan bagian yang urgen dalam suatu organisasi yang berfungsi sebagai alat untuk pencapaian tujuan atau sasaran yang ingin dicapai, (2) Motivasi kerja mengandung dua tujuan utama dalam diri individu yaitu untuk memenuhi kebutuhan atau keinginan pribadi dan tujuan organisasi, dan (3) Motivasi kerja yang diberikan kepada seseorang hanya efektif manakala di dalam diri seseorang itu memiliki kepercayaan atau keyakinan untuk maju dan berhasil dalam organisasi.

Pada prinsipnya modal usaha terbagi atas 2 jenis, yaitu modal pinjaman (debt) dan modal sendiri (equity). Kedua jenis modal tersebut masing-masing memiliki kelebihan dan kekurangannya, baik dilihat dari sumber modal itu diperoleh, jangka waktu dan biaya modalnya. (Ross, Westerfield \& Jordan, 2012). Modal usaha ini merupakan komponen utama yang harus dimiliki sebelum memulai sebuah bidang usaha. Tak sedikit yang kebingungan untuk mendapatkan modal, meski telah merancang konsep usaha yang akan dirintis sebelumnya. Berikut ini disampaikan beberapa pilihan sumber modal yang dapat dilakukan untuk memulai usaha, utamanya untuk usaha kecil dan UMKM, diantaranya yaitu modal usaha dari Bank, modal dari keluarga, penggalangan dana, menjual aset, dan menggadaikan aset.

Untuk memperoleh modal usaha ke bank, maupun untuk menilai kinerja sebuah usaha maka kemampuan menyusun sebuah laporan 
dan catatan keuangan yang baik menjadi suatu yang hal penting untuk diketahui dalam menjaga kelangsungan usahanya (John, Van Horn \& John M.W, 2009). Untuk menyusun sebuah laporan keuangan maka kita perlu tahu dan mengerti dalam melakukan pembukuan. Pembukuan usaha dapat dilakukan dengan melalukan pencatatan pemasukan dan pengeluaran yang terjadi pada aktivitas bisnis yang dijalankan (Weygandt, J. J., Kimmel, P. D., \& Kieso, D. E., 2010).

Berikut adalah tahapan-tahapan untuk melakukan pencatatan tersebut, yaitu a. pencatatan pembelian bahan baku, b. pencatatan biaya operasional dan Menyusun laporan laba rugi dan Neraca. Biaya operasional untuk perusahaan memproduksi barang jadi pada umumnya terdiri dari Biaya Administrasi Umum dan Biaya Pemasaran (Anitasari, N., 2017).

\section{METODE KEGIATAN}

Kegiatan pengabdian ini diikuti oleh para penyandang disabilitas baik yang belum punya usaha maupun yang telah tergabung dalam kelompok usaha di wilayah Kecamatan Sukajadi Kota Bandung. Metode pelaksanaan PkM nya meliputi kegiatan program pelatihan yang terdiri dari pelatihan motivasi usaha, rencana bisnis, sumber modal usaha dan penyusunan laporan keuangan sederhana, yang menghadirkan fasilitator yang berkompeten di bidang penyandang disabilitas, ahli motivator, pelaku UMKM serta dosen-dosen manajemen keuangan dan akuntansi dari Universitas Bakrie untuk memberikan materi pelatihannya kepada seluruh peserta PkM.

\section{Gambaran IPTEK}

Gambaran Iptek yang akan ditransfer pada kegiatan PkM ini adalah transfer teknologi kepada penyandang disabilitas, yaitu :

a. Kemampuan mengakses sumber modal usaha baik secara konvensional maupun melalui platform secara online.

b. Kemampuan menawarkan produk yang telah mereka buat melalui media promosi yang ada baik yang bersifat tradisional seperti leaflet / brosur, atau melalui media sosial dan atau marketplace.

c. Kemampuan membangun komunikasi dan kerjasama dengan UMKM setempat.

\section{Jadwal Pelaksanaan Kegiatan}

Persiapan dilakukan selama 2 bulan sebelum jadwal kegiatan akan dilakukan. Persiapan yang dilakukan meliputi koordinasi topik, wilayah kegiatan, survei lokasi, rapat koordinasi, dan penyiapan materi. Survei lokasi dilakukan untuk mengetahui kondisi tempat acara pelatihan akan dilakukan dan fasilitas serta penunjang lainnya yang sudah dan yang perlu disediakan.

Salah satu tujuan dari rapat koordinasi dilakukan untuk memilih materi pelatihan apa yang akan disampaikan pada saat pelaksanaan kegiatan. Pemilihan materi pelatihan disesuaikan dengan kebutuhan peserta PkM dan disesuaikan pula dengan bidang keahlian dari masing-masing dosen yang terlibat dalam 
kegiatan PkM serta instruktur lain yang dibutuhkan. Kegiatan pelatihan dilakukan dalam waktu 2 hari selama 5 jam per hari, yang terbagi dalam 2 sesi per hari dengan durasi masingmasing sesi adalah 2,5 jam. Setiap sesi dibawakan oleh seorang instruktur/dosen sebagai penanggung jawab kegiatan sekaligus sebagai narasumber, dan dibantu oleh fasilitator lain yang kompeten dan mahasiswa Universitas Bakrie yang ikut serta dalam membantu kegiatan PkM tersebut.

\section{Tolak Ukur Keberhasilan Kegiatan}

Tolak ukur keberhasilan program pelatihan ini dilakukan dengan menyebarkan kuesioner pre-test dan post-test kepada peserta pelatihan mengenai pemahaman terhadap seluruh materi yang disampaikan. Apabila hasil post-test menunjukkan hasilnya lebih baik dibandingkan hasil pre-test maka menunjukkan keberhasilan program pelatihan tersebut, dan sebaliknya apabila hasil post-test lebih kecil dari hasil pretest menunjukkan ketidak berhasilan dan kurang efektifnya program pelatihan yang dilakukan.

\section{HASIL DAN PEMBAHASAN}

Kegiatan Pengabdian kepada Masyarakat (PkM) dilaksanakan sesuai surat perjanjian/kontrak pengabdian di lingkungan Universitas Bakrie dengan nomor 040/SPK/LPkM-UB/III/2021. Sesuai SK tersebut kegiatan PkM berjudul "Program Pelatihan Motivasi Usaha, Sumber Modal Usaha dan Penyusunan Laporan Keuangan pada
Penyandang Disabilitas dan Kelompok Usaha di Wilayah Kecamatan Sukajadi Kota Bandung". Adapun Tim Pelaksana PkM sendiri terdiri dari : Dr. Dudi Rudianto, SE., MSi (Ketua Tim Pengabdian), Monica Weni Pratiwi, S.E., M.Si. (Anggota Tim Pengabdian), Siti Zubaidah Chaidir (Anggota Mahasiswa Prodi S1 Manajemen) dan Nurusyifa (Anggota Mahasiswa Prodi Akuntansi). Awalnya rencana program pelatihan PkM ini akan dilaksanakan secara online (daring) dengan menggunakan fasilitas Zoom karena dilaksanakan masih di masa pandemi dengan harapan juga akan bisa diikuti oleh banyak peserta, namun karena berbagai kendala dan keterbatasan yang dialami oleh peserta disabilitas baik karena masalah keterbatasan sarana teknologi maupun karena keterbatasan sebagai penyandang disabilitas, akhirnya pelaksanaan program pelatihan dilaksanakan secara offline (luring).

Program Pelatihan PkM dilaksanakan selama 2 (dua) hari yaitu tanggal 15 - 16 Maret 2021 bertempat di Aula Kecamatan Sukajadi Kota Bandung, yang diikuti oleh 18 peserta penyandang disabilitas dari 20 peserta awal yang sudah terdaftar, dengan menyesuaikan terhadap penggunaan maksimum 50\% dari kapasitas aula yang hanya bisa menampung pada kapasitas maksimum sebanyak 35 orang. Dari jumlah peserta sebanyak 18 orang tersebut terbagi atas cacat tubuh sebanyak 9 orang (baik cacat kaki maupun cacat tangan), 7 orang tuna netra dan 2 orang tuna rungu. 
Acara pembukaan pelatihan dilaksanakan pada hari Senin, tanggal 15 Maret 2021, dimulai pukul 08.30 yang diawali oleh penyampaian laporan kegiatan pelatihan oleh Ketua Tim Pelatihan yakni bapak Dr. Dudi Rudianto, SE., MSi., yang menginformasikan tentang jumlah peserta yang mengikuti kegiatan pelatihan, narasumber serta materi pelatihannya. Pembukaan kegiatan pelatihan sendiri secara resmi dilakukan oleh Ibu Pancariny, AMP selaku Kepala Seksi Kesejahteraan Sosial Kecamatan Sukajadi Kota Bandung yang mewakili Bapak Camat yang agak terlambat hadir saat acara pembukaan.

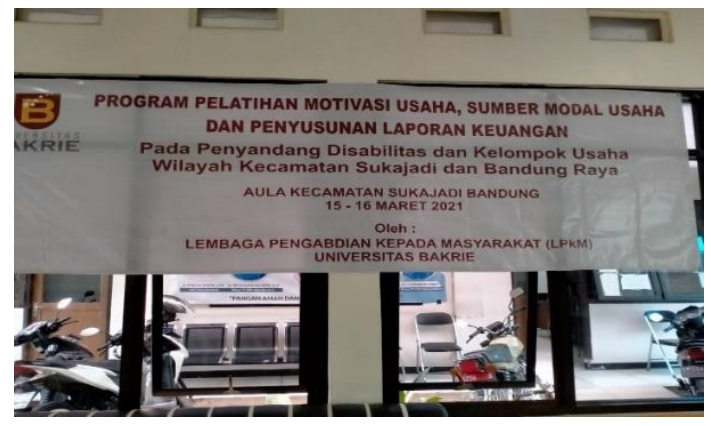

Gambar 1. Spanduk Acara Pelatihan

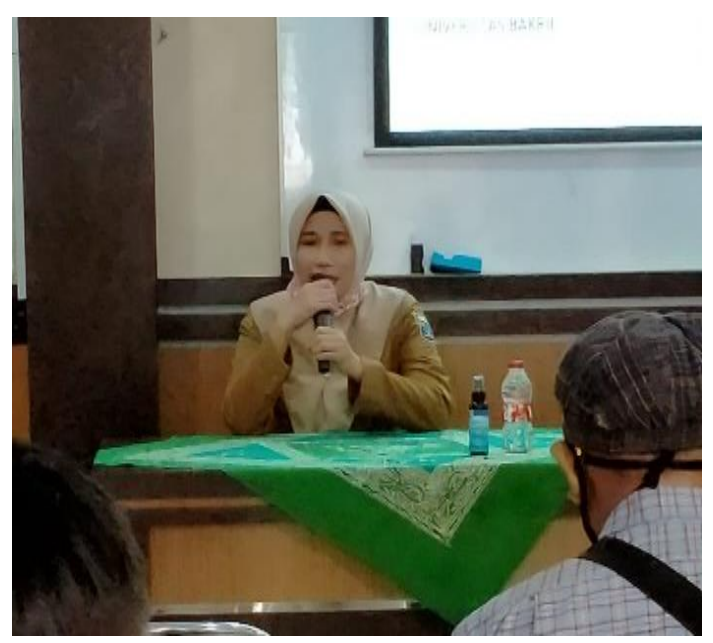

Gambar 2. Pembukaan Acara Pelatihan Oleh Ibu Pancariny AMP, Kasi Kesos Kec. Sukajadi Bandung

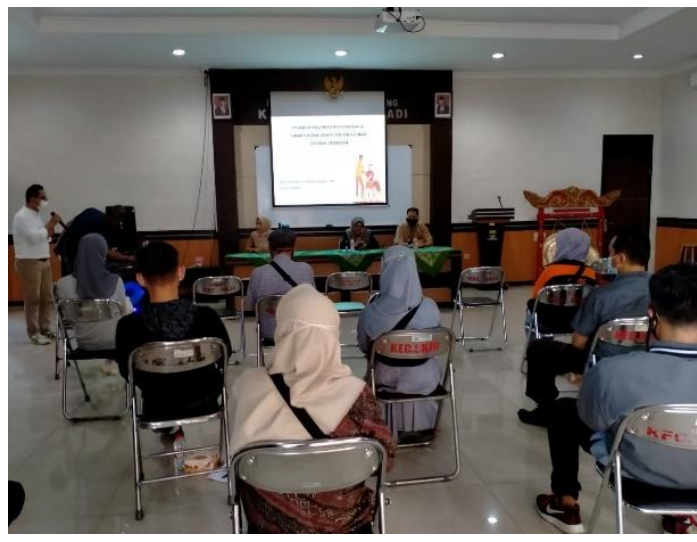

Gambar 3. Suasana Acara Pembukaan Pelatihan

Tepat pukul 09.00 pelatihan sesi 1 tentang motivasi usaha disampaikan oleh Bapak Dudu Hafidz. Beliau adalah seorang penyandang tuna netra, sebagai Founder dan Ketua Yayasan Daya Inspirasi Disabilitas Indonesia, Founder ketua Koperasi Daya Wirabilitas Indonesia dan juga sebagai Pimpinan CV Mandiri Daya Group yang bergerak di bidang Diffs Reflexology, Diffs Food, Diffs Catering dan Diffs Laundry.

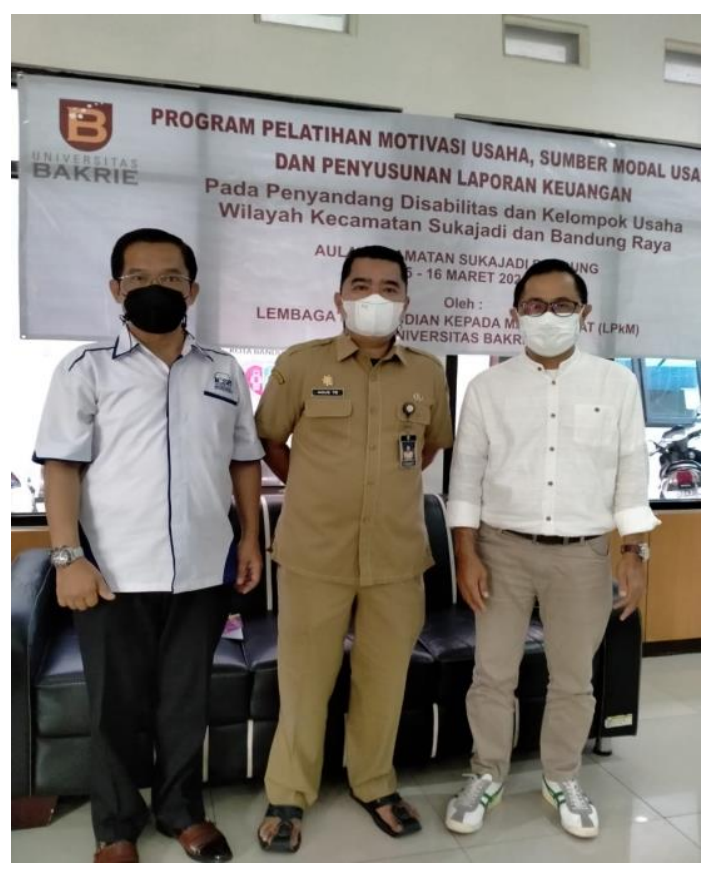

Gambar 4. Foto bersama dengan Bapak Camat Kec. Sukajadi Bandung

Sebelum materi disampaikan, terlebih dahulu diedarkan kuesioner pre-test tentang 
materi motivasi usaha. Salah satu pertanyaan dari soal pre-test tersebut mengenai seberapa besar keyakinan peserta untuk bisa membuka usaha sebagai pengusaha, sebagian besar peserta memberikan jawaban kurang dan tidak yakin, dan terkandung nada pesimistis para peserta untuk bisa membuka usaha, dan yang menyatakan keyakinan usaha hanya ada $60 \%$. Setelah selesai pre-test, berikutnya adalah pemaparan materi tentang motivasi usaha.

Materi ini disampaikan dengan penuh semangat dan menarik oleh narasumber, mengingat narasumber sendiri merupakan penyandang disabilitas yakni tuna netra, sehingga beliau memiliki pengalaman panjang dan merasakan sendiri bahwa masih adanya perlakuan diskriminatif dari kalangan masyarakat dan industri terhadap keberadaan dan kesangsian keterbatasan yang dimiliki oleh penyandang disabilitas untuk bisa berinteraksi dengan masyarakat, sehingga para penyandang disabilitas dituntut harus bisa hidup mandiri baik secara ekonomi maupun secara sosial. Salah satunya yaitu harus bisa menciptakan usaha sendiri sesuai kemampuan dan keterampilan yang dimiliki masing-masing.

Menurut Bapak Dudu Hafidz bahwa ada beberapa cara efektif untuk memunculkan dan meningkatkan motivasi diri untuk memulai usaha, beberapa diantaranya adalah :

a. bergabung ke komunitas bisnis yang tepat, b. banyak membaca cerita sukses usaha orang lain,

c. jadikan hinaan sebagai cambuk untuk terus berusaha secara giat dan semangat,

d. mencari partner bisnis yang tepat,

e. banyak-banyak berdoa untuk keberhasilan usahanya,

f. selalu memikirkan orang-orang yang kita cintai,

g. selalu berpikir optimis dan yakin. Dengan selalu berpikir optimis dan yakin maka pikiran kita pasti akan terasa lebih tenang dan lebih termotivasi untuk mewujudkan rencana usahanya dengan baik.

Materi yang disampaikan oleh Bapak Dudu Hafidz diselesaikan dalam waktu 2 jam dan di akhir materi, dan seluruh peserta (100\%) menyatakan keyakinannya yang tinggi untuk bisa hidup mandiri dengan memiliki usaha sendiri.

\section{Perbandingan Tingkat Keyakinan \\ Usaha Pre \& Post Test Materi Motivasi Usaha}

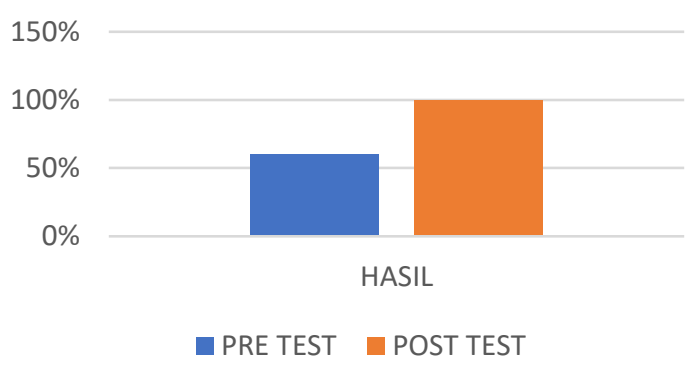

Grafik 1. Perbandingan Tingkat Keyakinan Usaha Pre \& Post Test Materi Motivasi Usaha 


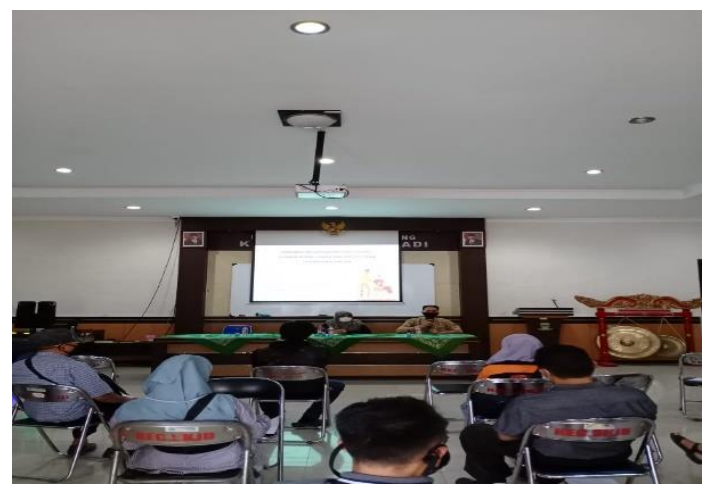

Gambar 5. Penyampaian Materi Motivasi Usaha oleh Bapak Dudu Hafidz

Materi selanjutnya dimulai pukul 11.00 13.00 WIB,yaitu tentang rencana bisnis. Materi kedua ini disampaikan secara paralel oleh Ibu Ir. Yani Mulyani sebagai pelaku UMKM yang telah melakukan kemitraan usaha dengan penyandang disabilitas, yang juga sebagai Sekretaris Majelis Kesejahteraan Sosial Cabang Aisyiyah Sukajadi dan sebagai pengurus komunitas UMKM di wilayah Kecamatan Sukajadi, bersama dengan Bapak Ir. Amir Mideva, dimana beliau adalah sebagai Ketua ICSB (International Consult for Small Business) Korwil Kota Bandung. Sebelum materi disampaikan oleh kedua narasumber, terlebih dahulu diedarkan soal pre-test untuk mengetahui pengetahuan peserta tentang perencanaan usaha (bisnis), dan diperoleh hasil nilainya rata-rata 70 (70\%).

Setelah pengerjaan pre-test selesai dilakukan selanjutnya disampaikan paparan materi tentang rencana bisnis. Kedua narasumber memaparkan materinya dengan sangat menarik yaitu tentang langkah-langkah praktis untuk memulai rencana usaha. Menurut mereka berdua mengatakan bahwa pada prinsipnya terdapat 7 langkah praktis yang perlu dilakukan untuk memulai rencana usaha, yaitu :
a. menjabarkan deskripsi bisnis,
b. menyusun strategi pemasaran,
c. membuat analisis kompetitor,
d. memperhatikan rencana desain dan pengembangan,

e. menyusun rencana operasional dan manajemen,

f. masalah pembiayaan,

g. membuat kesimpulan atau resume rencana bisnis.

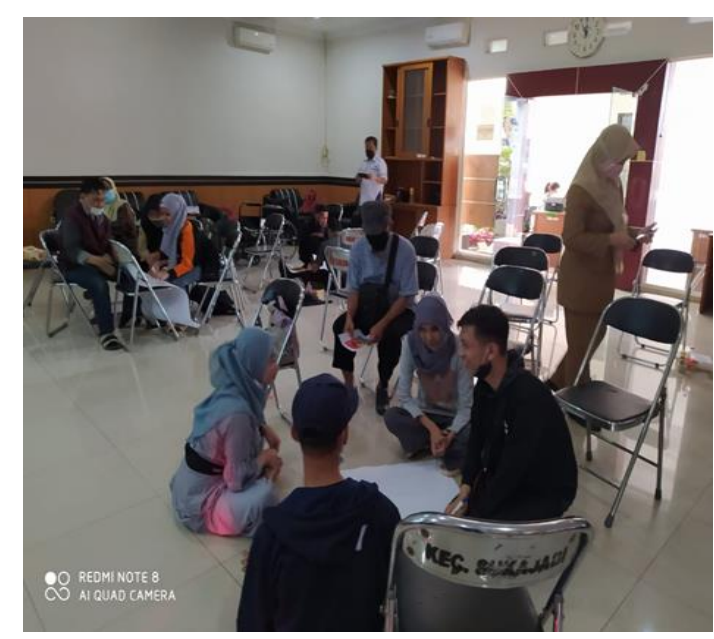

Gambar 6. Simulasi Rencana Bisnis

Untuk lebih memahami dan mendalami materi pelatihan secara menarik, maka seluruh peserta dibagi atas 4 kelompok rencana usaha, dimana masing-masing kelompok bertugas untuk membuat simulasi rencana bisnisnya masing-masing lengkap dengan anggaran biayanya. Adapun pembagian kelompok dan rencana bisnisnya adalah sebagai berikut: 
Tabel 1. Daftar Pembagian Kelompok Simulasi Rencana Bisnis

\begin{tabular}{clc}
\hline $\begin{array}{c}\text { Nama } \\
\text { kelompok }\end{array}$ & \multicolumn{1}{c}{$\begin{array}{c}\text { Anggota } \\
\text { kelompok }\end{array}$} & $\begin{array}{c}\text { Rencana } \\
\text { Bisnis }\end{array}$ \\
\hline Kelompok 1 & $\begin{array}{l}\text { 1. Lastyono R } \\
\text { 2. Ajeng }\end{array}$ & Juice NI \\
& $\begin{array}{c}\text { 3. Neneng N } \\
\text { 4. Nina R }\end{array}$ & \\
& 5. Elim E. & \\
\hline Kelompok 2 & 1. Siti Mariam & Jahit \\
& 2. Evie R. & \\
& 3. Resti & \\
& 4. Khaerunisa & \\
\hline Kelompok 3 & 1. Alifa & Kuliner \\
& 2. Soni & Cemilan \\
& 3. Yusuf & Cilok \\
& 4. Subarnas & \\
\hline Kelompok 4 & 1. Cahyadi & Usaha \\
& 2. Agus & Parfum \\
& 3. Irdan & \\
& 4. Asep & \\
& 5. Andi & \\
\hline
\end{tabular}

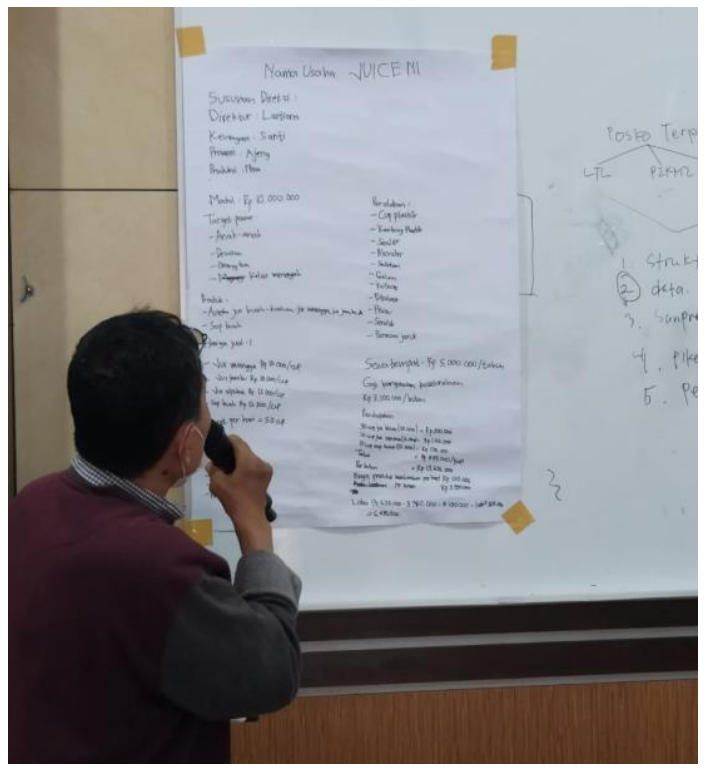

Gambar 7. Presentasi Simulasi Rencana Per Kelompok Bisnis

Nilai post-test pada materi ini hasilnya ratarata peserta memperoleh nilai yang tinggi yaitu nilai 100 atau betul semua (100\%). Dari materi simulasi rencana bisnis ini terlihat peserta begitu sangat antusias untuk menggarap sebuah rencana usaha yang bisa mereka jalankan dan prospeknya di masa depan terlebih dalam menghadapi bulan puasa ramadhan dan lebaran. Rencana usaha yang akan mereka jalankan adalah rencana usaha yang mampu dijangkau oleh keadaan ekonomi dan kondisi disabilitasnya masing-masing, yaitu usaha kuliner, parfum dan keterampilan jahit. Acara pelatihan hari pertama ditutup pada pukul 13.00 WIB, dilanjutkan dengan ishoma serta evaluasi dan persiapan pelatihan hari kedua besok.

\section{Perbandingan Nilai Pre \& Post Test Materi Rencana Usaha}

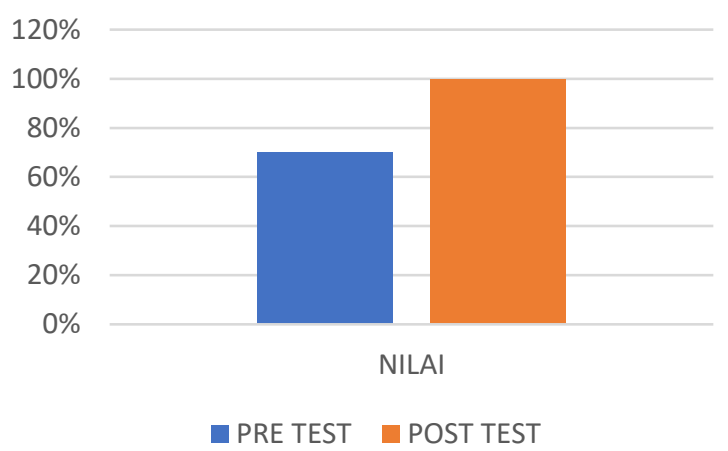

Grafik 2. Perbandingan Nilai Pre \& Post Test Materi Rencana Usaha

Acara pelatihan berikutnya dilanjutkan pada hari Selasa, tanggal 16 Maret 2021, dimana materi pertama pada hari kedua dilakukan mulai pukul 08.30 - 10.30 WIB dengan materi tentang sumber modal usaha. Materi ini disampaikan oleh bapak Dr. Dudi Rudianto, SE., MSi, sebagai dosen tetap program studi Magister Manajemen di Universitas Bakrie dengan bidang ilmunya di bidang keuangan. Materi tentang sumber modal usaha menjadi bagian yang penting dan menarik bagi peserta, karena rencana bisnis yang bagus perlu ditunjang oleh pilihan sumber modal yang 
memadai. Sebelum materi disampaikan, terlebih dahulu diedarkan kuesioner pre-test kepada peserta tentang pemahaman sumber modal usaha, hasilnya dari 5 pertanyaan yang disampaikan, hanya $30 \%$ peserta yang mengetahui jenis-jenis sumber modal usaha serta kelebihan dan kelemahannya masingmasing.

Secara garis besar terdapat 12 pilihan sumber modal usaha untuk usaha kecil dan UMKM, yaitu meminjam dari bank dengan Jaminan, meminjam dari bank tanpa Jaminan (Agunan), menggunakan tabungan, menjual aset yang dimiliki, menggadaikan aset yang dimiliki, meminjam dari teman atau saudara, dana dari ikut serta pelatihan, Joint Venture, modal dari konsumen, franchise (Waralaba), sponsor dari website, meminjam dari koperasi. Hasil post-test pada materi sumber modal ini rata-rata peserta mampu menjawab 90\% dengan baik sehingga peserta mengetahui bebagai macam pilihan sumber modal usaha serta kelebihan dan kelemahannya masing-masing.

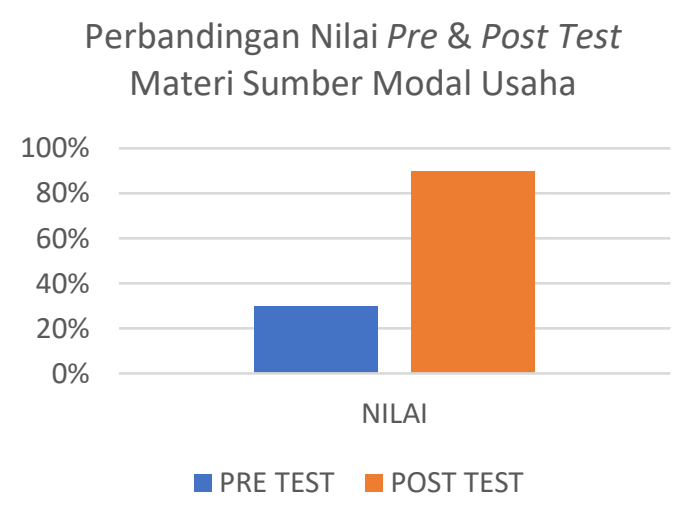

Grafik 3. Perbandingan Nilai Pre \& Post Test Materi Sumber Modal Usaha

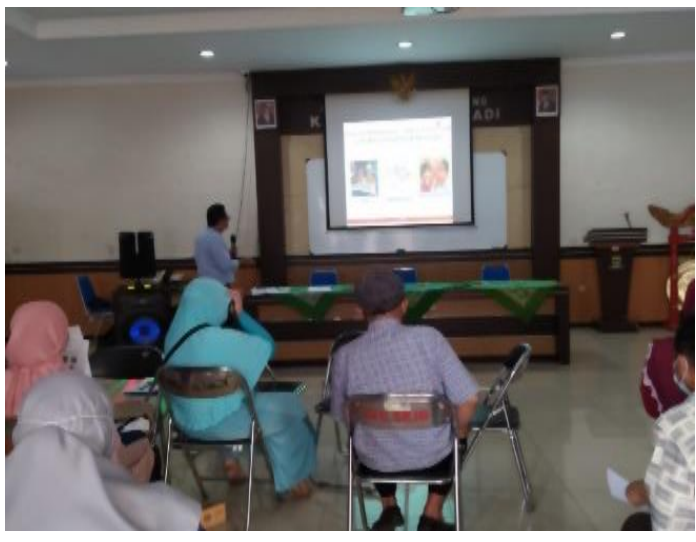

Gambar 8. Materi Sumber Modal Usaha

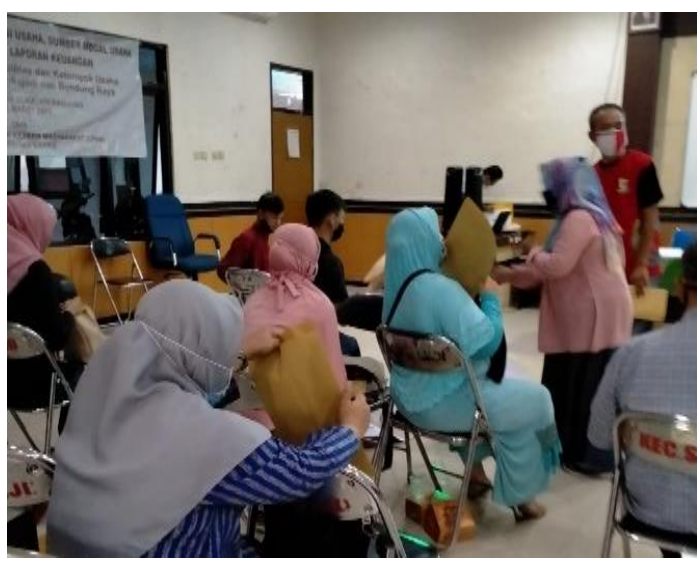

Gambar 9. Suasana Pelatihan Hari Kedua

Materi berikutnya pada pelatihan hari kedua, yaitu tentang Penyusunan Laporan dan Catatan Keuangan sederhana bagi usaha kecil dan UMKM. Materi ini disusun oleh Ibu Monica Weni Pratiwi, SE.,MSi. Beliau adalah Dosen Tetap Program Studi S1 Akuntansi Universitas Bakrie dengan bidang IImu Pengantar Akuntansi dan Akuntansi Keuangan. Seperti biasa sebelum disampaikan materi, terlebih dahulu diedarkan pertanyaan pre-test kepada peserta mengenai proses penyusunan laporan dan catatan keuangan sederhana. Dari 10 pertanyaan, hanya 40\% yang dapat menjawab dengan benar. Materi Ibu Monica Weni, secara langsung disampaikan oleh Bapak Dr. Dudi Rudianto, mengingat kondisi kesehatan Ibu Monica weni yang sedang 
terganggu dan domisili di Jakarta. Materi tersebut menjelaskan bahwa terdapat 8 catatan penting yang perlu diperhatikan dalam menyusun sebuah laporan keuangan yang sehat bagi usaha kecil dan UMKM. Ke-8 catatan tersebut adalah sebagai berikut :

1) Kemampuan untuk bisa memisahkan secara jelas antara kebutuhan uang untuk keperluan pribadi atau keluarga dan uang untuk keperluan usaha.

2) Rencanakan setiap penggunaan dana usaha prioritas untuk pengembangan usaha jangka panjang dan kesinambungan usahanya.

3) Menyusun buku kas harian.

4) Menyusun buku persediaan barang.

5) Menyusun Laporan Laba Rugi setiap bulannya.

6) Kemampuan memutar uang lebih cepat.

7) Menyusun dan mengawasi setiap catatan utang piutang dari usaha kita.

8) Kemampuan untuk menyisihkan setiap perolehan keuntungan untuk upaya pengembangan usaha kita di masa depan, agar bisa maju dan lebih berkembang lagi.

Setelah materi selesai disampaikan, selanjutnya adalah pengisian post-test tentang penyusunan dan laporan keuangan usaha sederhana, dan hasilnya secara menyeluruh ratarata peserta dapat menjawab dengan baik dengan nilai rata-rata sebesar 80\%. Acara pelatihan hari kedua diselesaikan pada jam 13.00 dan dilanjutkan dengan ishoma.
Perbandingan Nilai Pre \& Post Test

Materi Catatan \& Laporan Keuangan Usaha

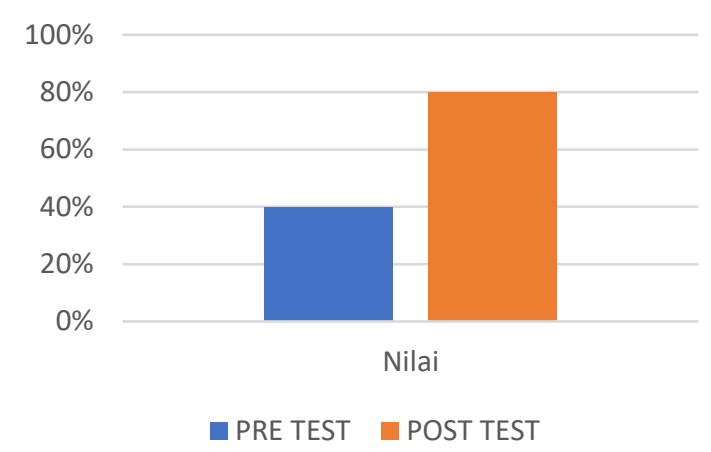

Grafik 4. Perbandingan Nilai Pre \& Post Test Materi Catatan \& Laporan Keuangan Usaha

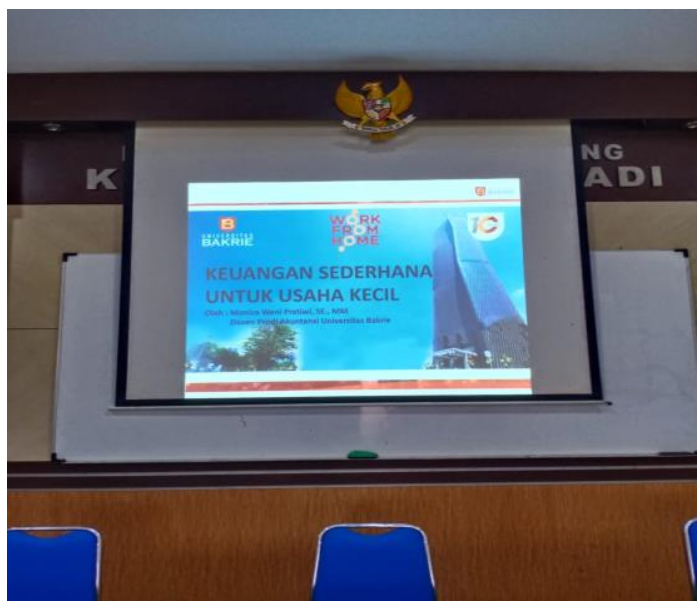

Gambar 10. Materi Laporan Keuangan Usaha

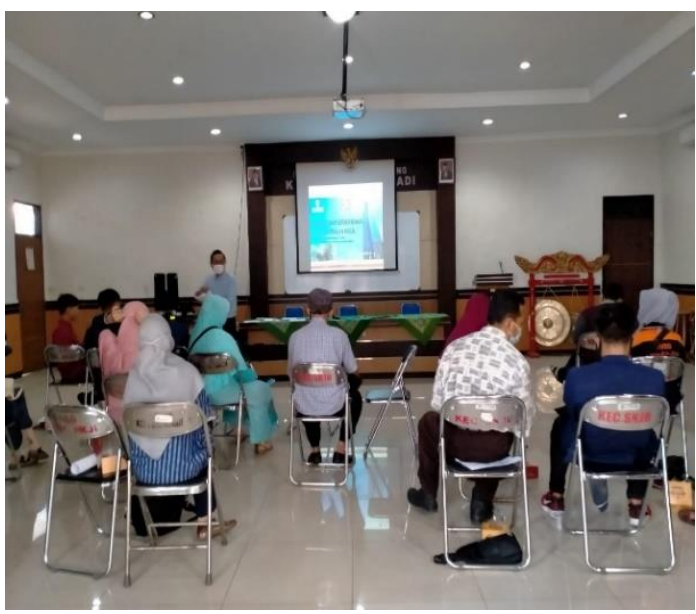

Gambar 11. Suasana Pelatihan Hari Kedua

Selanjutnya di akhir acara pelatihan pada hari kedua Selasa, tanggal 16 Maret 2021, adalah acara penutupan. Acara penutupan pelatihan 
diawali dengan laporan oleh ketua panitia yakni Bapak Dr. Dudi Rudianto, SE., MSi, yang juga mewakili pihak Lembaga Pengabdian kepada Masyarakat (LPkM) Universitas Bakrie untuk melaporkan seluruh rangkaian kegiatan pelatihan selama 2 hari dan penyampaian ucapan terima kasih kepada pihak Kecamatan Sukajadi, seluruh jajaran panitia dan peserta pelatihan. Dan setelahnya dilakukan pembagian sertifikat baik kepada seluruh peserta maupun kepada perwakilan narasumber. Setelah itu acara ditutup dengan foto bersama dengan seluruh peserta, panitia acara, narasumber serta perwakilan dari pihak Kecamatan Sukajadi.

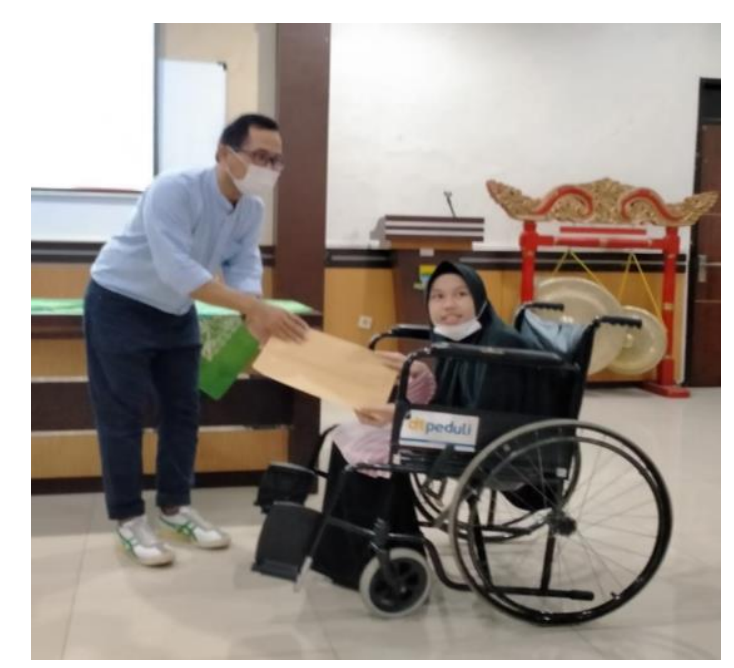

Gambar 12. Pembagian sertifikat secara simbolis kepada wakil peserta

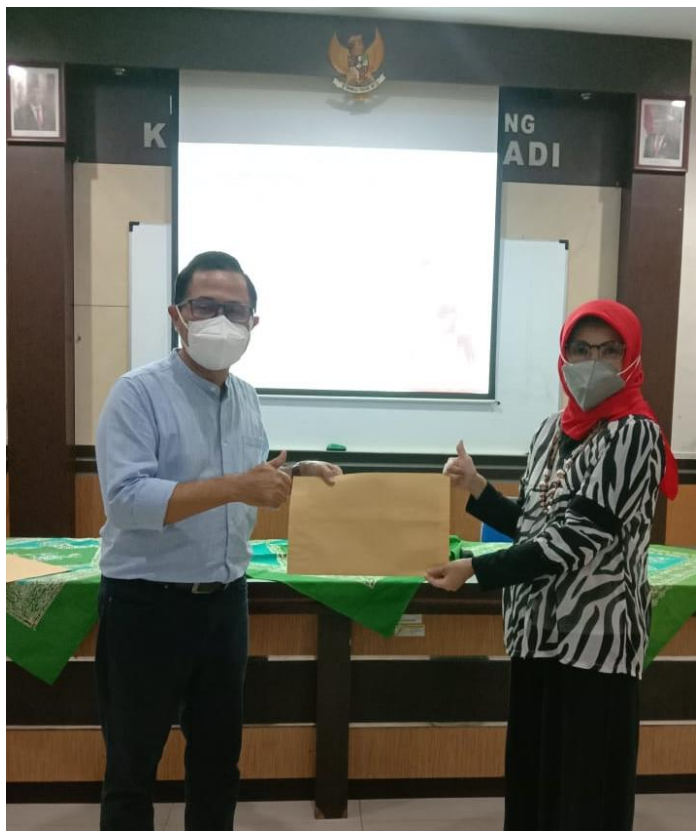

Gambar 13. Pembagian sertifikat secara simbolis kepada wakil narasumber

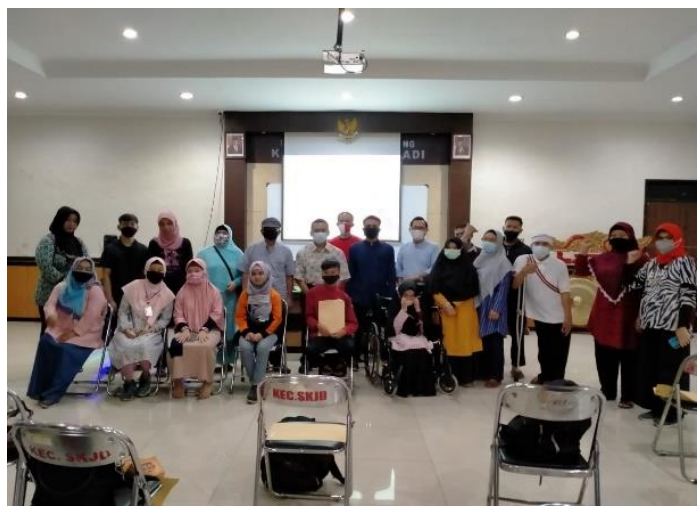

Gambar 14. Foto bersama -1

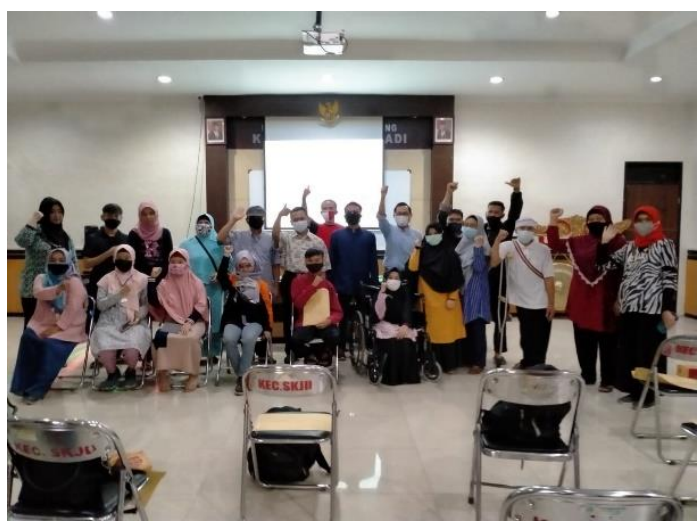

Gambar 15. Foto bersama - 2

Setelah acara penutupan selesai, dilakukan testimoni kesan dan pesan dari 3 orang perwakilan peserta tanggapannya terhadap kegiatan acara pelatihan. Dan semuanya 
memberikan tanggapan dan apresiasi yang positif terhadap penyelenggaraan acara. Dan diharapkan ada tindak lanjutnya dari acara pelatihan, diantaranya adanya upaya untuk merealisasikan rencana pembuatan usaha dari masing-masing peserta.

Upaya untuk menginisiasi tindak lanjut dari acara pelatihan, yaitu dengan dibentuknya WA Group yang terdiri dari seluruh peserta, panitia, narasumber dan pihak kecamatan Sukajadi, sebagai media informasi, diskusi dan bertukar pikiran tentang upaya-upaya untuk membuka usaha baru dan persyaratannya. Dan upaya ini sangat direspon positif oleh seluruh peserta secara antusias. Kegiatan acara pelatihan tersebut dimuat pada Harian Umum "Pikiran Rakyat", edisi tanggal 16 Maret 2021 pada rubrik pendidikan.

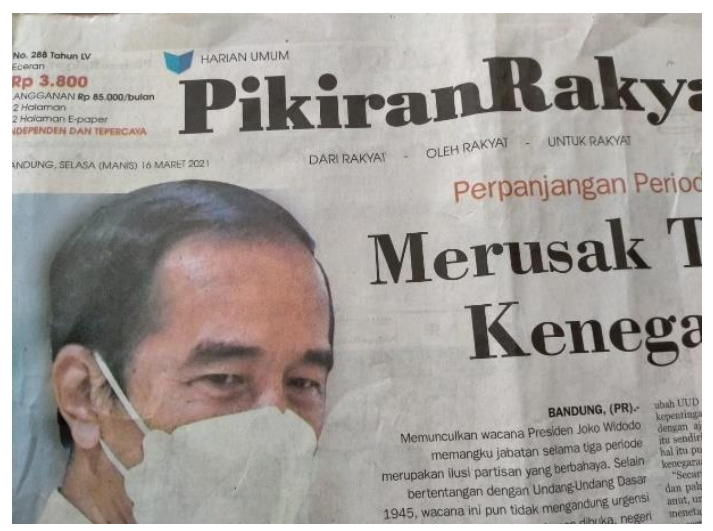

Gambar 16. Liputan acara pelatihan pada HU “Pikiran Rakyat" edisi 16 Maret 2021 Halaman depan

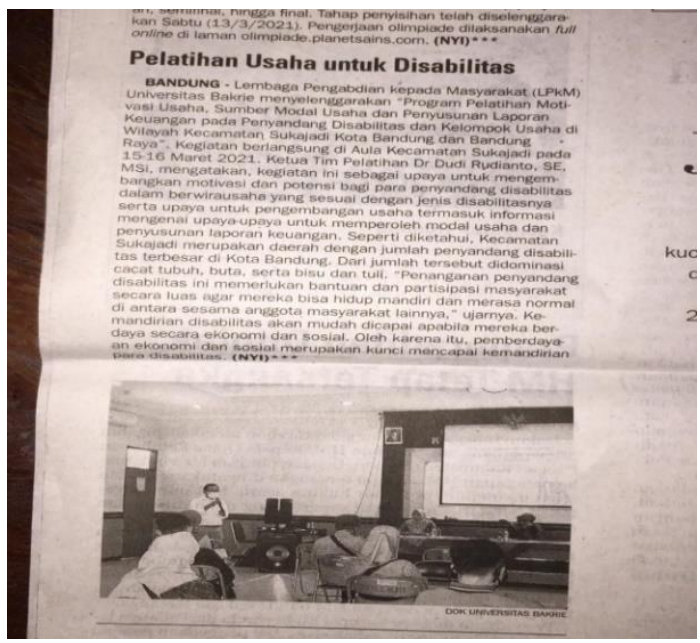

Gambar 17. Liputan Acara Pelatihan pada HU "Pikiran Rakyat" edisi 16 Maret 2021 Rubrik Pendidikan

\section{KESIMPULAN}

Kegiatan PkM yang dijalankan adalah Program Pelatihan Motivasi Usaha, Rencana Bisnis, Sumber Modal Usaha dan Penyusunan Laporan Keuangan bagi Penyandang Disabilitas di Wilayah Kecamatan Sukajadi Kota Bandung yang dilaksanakan secara offline (luring) selama 2 hari yaitu tanggal 15 - 16 Maret 2021, bertempat di Aula Kecamatan Sukajadi Kota Bandung. Peserta yang mengikuti pelatihan berjumlah 18 orang sebagai penyandang disabilitas, dengan kriteria 9 orang cacat tubuh (kaki dan tangan), 7 orang tuna netra dan 2 orang tuna rungu.

Terdapat 5 narasumber yang berkompeten yang terlibat dalam pelatihan ini, yaitu Bapak Dudu Hafidz, beliau adalah penyandang tuna netra, sekaligus sebagai Founder dan Ketua Yayasan Daya Inspirasi Disabilitas Indonesia, sebagai Founder Ketua Koperasi Daya Wirabilitas Indonesia, Pimpinan CV Mandiri Daya Group (Diffs Reflexology, Diffs Food, Diffs Catering \& Diffs Laundry), beliau menyampaikan materi 
tentang cara efektif untuk meningkatkan motivasi usaha. Narasumber kedua dilakukan secara paralel oleh Ibu Ir. Yani Mulyani, beliau adalah Pelaku UMKM yang telah bermitra dengan Kaum Disabilitas, sebagai Sekretaris Majelis Kesejahteraan Sosial pimpinan cabang Aisyiyah Sukajadi dan sebagai Pengurus komunitas UMKM Kecamatan Sukajadi Kota Bandung. Serta Bapak Ir. Amir Mideva Madyana, beliau adalah Ketua ICSB Korwil Kota Bandung. Kedua narasumber tersebut menyampaikan materi tentang langkah-langkah praktis dalam membuat rencana bisnis. Narasumber berikutnya adalah Bapak Dr. Dudi Rudianto, SE., MSi., beliau adalah Dosen Tetap di Prodi MM Universitas Bakrie, dengan bidang ilmu Manajemen Keuangan yang menyampaikan materi tentang sumber modal usaha. Dan narasumber terakhir adalah Ibu Monica Weni Pratiwi, SE., MSi. Beliau adalah Dosen Tetap di Prodi S1 Akuntansi Universitas Bakrie dengan bidang Ilmu Pengantar Akuntansi dan Akuntansi Keuangan yang menyusun materi tentang laporan dan cacatan keuangan sederhana untuk usaha kecil dan UMKM.

Terdapat 4 materi pelatihan yang disampaikan yaitu a). materi cara efektif untuk meningkatkan motivasi usaha. Bahwa ada 10 cara efektif untuk meningkatkan motivasi usaha, meliputi: bergabung pada komunitas bisnis yang tepat, membaca cerita sukses usaha orang lain, membayangkan seperti apa usaha kita kelak, membuat perencanaan usaha, menjadikan hinaan sebagai cambuk untuk terus berusaha, mencari partner bisnis yang tepat, menghargai proses sebagaimana hasil, terus berdoa, memikirkan mereka yang kita cintai, dan selalu berpikir optimis dan yakin. b). langkah-langkah praktis dalam membuat rencana bisnis. Bahwa terdapat 7 langkah praktis untuk membuat rencana bisnis, yaitu menjabarkan deskripsi bisnis, menyusun strategi pemasaran, membuat analisis kompetitor, memperhatikan rencana desain dan pengembangan, menyusun rencana operasional dan manajemen, rencana pembiayaan, dan membuat kesimpulan dari rencana bisnisnya apakah akan jalan atau perlu dikoreksi kembali. c). sumber modal usaha. Terdapat 12 cara untuk memperoleh modal usaha, yaitu meminjam dari bank dengan jaminan, meminjam dari bank tanpa jaminan (agunan), menggunakan tabungan, menjual aset yang kita miliki, menggadaikan aset yang kita miliki, meminjam dari teman atau saudara, mengikuti pelatihan, joint venture, menggunakan modal dari konsumen, franchise (waralaba), sponsor dari website, meminjam dari koperasi. d). penyusunan laporan dan cacatan keuangan sederhana untuk usaha kecil dan UMKM. Terdapat 8 catatan keuangan yang penting yaitu : memisahkan secara jelas antara kebutuhan uang untuk keperluan pribadi atau keluarga dan uang untuk keperluan usaha, rencanakan setiap penggunaan dana usaha prioritas untuk pengembangan usaha jangka panjang dan kesinambungan usahanya, menyusun buku kas 
harian, menyusun buku persediaan barang, menyusun Laporan Laba Rugi setiap bulannya, memutar uang lebih cepat, menyusun dan mengawasi setiap catatan utang piutang dari usaha kita, kemampuan untuk menyisihkan setiap perolehan keuntungan untuk upaya pengembangan usaha kita di masa depan.

Setelah mengikuti program pelatihan ini, seluruh peserta merasakan manfaat dan dampak positif yang diperoleh. Hal ini dibuktikan dengan dipahaminya seluruh materi pelatihan dengan baik oleh peserta, yang ditunjukkan oleh hasil post-test yang menunjukkan nilai yang jauh meningkat dibandingkan dengan hasil saat pretest, masing-masing meningkat $40 \%$ untuk materi motivasi usaha, $30 \%$ untuk materi rencana bisnis, $60 \%$ untuk materi sumber modal usaha dan $40 \%$ untuk materi penyusunan laporan keuangan. Hasil dari program pelatihan ini diikuti pula keinginan para peserta untuk mengimplementasikan dari program pelatihan dalam bentuk pendampingan untuk menjadi pengusaha yang sebenarnya. Kondisi ini ditunjukkan oleh video testimoni dari beberapa wakil dari peserta. Keinginan peserta untuk menjadi pengusaha yang sebenarnya ini ditunjukkan oleh aktifnya para peserta pada WAG (WhatsApp Group) antar sesama peserta pelatihan dan semua narasumber, yang digunakan sebagai sarana diskusi, informasi dan komunikasi.

Salah satu bukti tindak lanjut dan implementasi dari kegiatan pelatihan, salah satu peserta ikut bergabung dengan UMKM usaha konveksi untuk mengikuti salah satu pameran yang diadakan di salah satu mall di Bandung, yaitu di BTM (Bandung Trade Mall).

\section{SARAN}

Dari program pelatihan ini, sesuai keinginan peserta agar ditindaklanjuti dalam bentuk upaya pendampingan untuk menjadi pengusaha yang sesungguhnya sesuai minat, bakat dan jenis disabilitasnya masing-masing.

Upaya pemberdayaan penyandang disabilitas memerlukan partisipasi aktif seluruh komponen masyarakat baik dari dinas sosial, pemerintah pusat dan daerah sampai di tingkat kecamatan maupun pihak perguruan tinggi agar mereka bisa hidup mandiri dan merasa "normal" diantara sesama anggota masyarakat lainnya melalui berbagai program pelatihan dan pendampingan.

Perlu sosialisasi dan edukasi kepada masyarakat yang dilakukan secara terus menerus, bahwa penyandang disabilitas bisa hidup berdampingan dengan masyarakat lainnya secara harmonis untuk menghasilkan karya yang berkualitas dan bisa saling bekerjasama dengan baik.

\section{TINDAK LANJUT}

Setelah mengikuti program pelatihan, seluruh peserta merasakan manfaat dan dampak positif yang diperoleh. Hasil ini ditunjukkannya dengan meningkatnya keinginan para peserta 
untuk mengimplementasikan serta adanya tindak lanjut dari program pelatihan dalam bentuk pendampingan untuk menjadi pengusaha yang sebenarnya. Keinginan peserta untuk menjadi pengusaha yang sebenarnya ini ditunjukkan oleh aktifnya para peserta dalam WAG (WhatsApp Group) antar sesama peserta pelatihan dan semua narasumber, yang digunakan sebagai sarana diskusi, informasi dan komunikasi tindak lanjutnya. Dari perbincangan pada WAG tersebut terlihat antusiasme keinguinan para peserta untuk membuat NIB (Nomor Induk Berusaha) dan IUMK (Izin Usaha Mikro kecil).

Bukti tindak lanjut dan implementasi lainnya dari kegiatan pelatihan tersebut, dimana salah satu peserta telah ikut bergabung dengan salah satu UMKM usaha konveksi untuk mengikuti salah satu pameran yang diadakan di salah satu mall di Bandung, yaitu di BTM (Bandung Trade Mall).

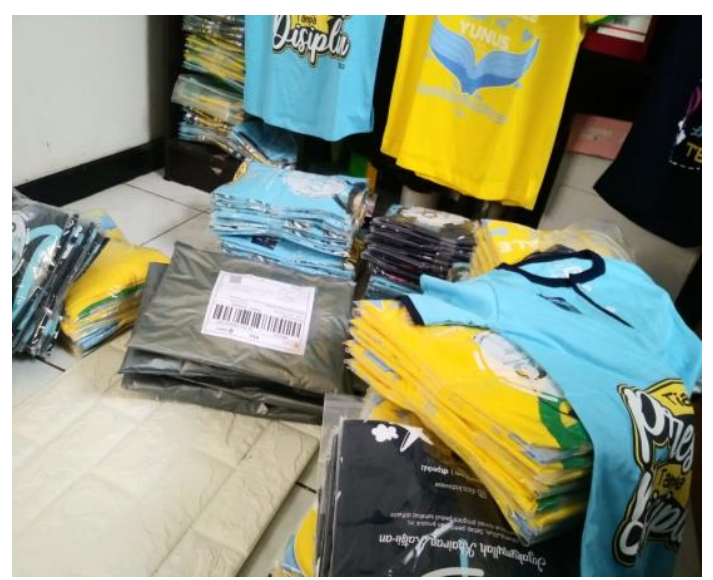

Gambar 18. Salah Satu Produk Peserta Pelatihan pada Pameran UMKM BTM Expo

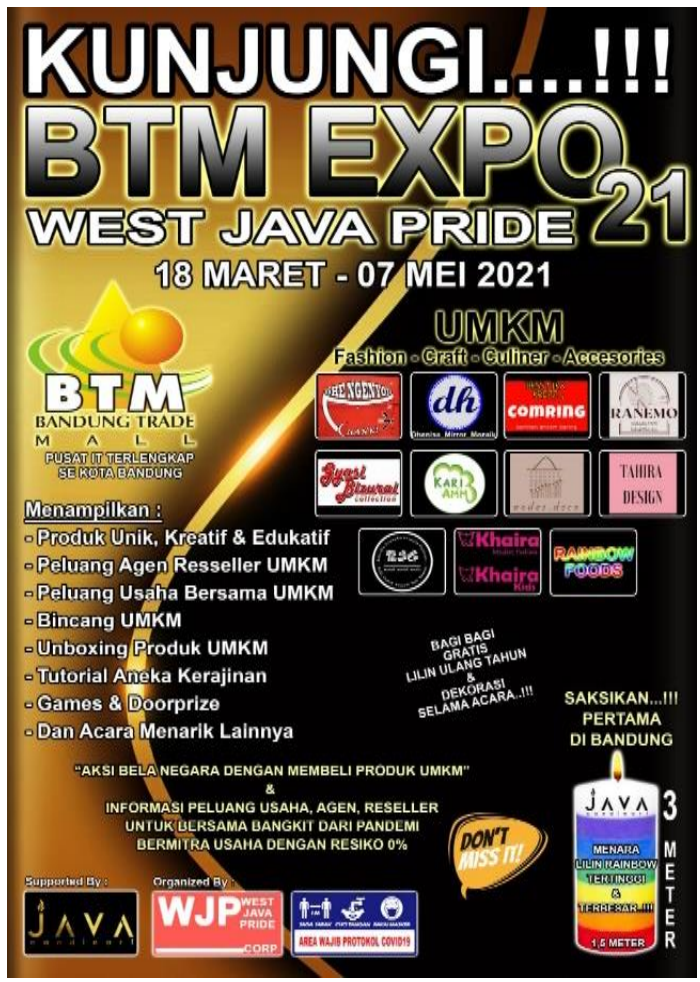

Gambar 19. Pameran UMKM BTM Expo

\section{UCAPAN TERIMA KASIH}

Terima kasih kepada Lembaga Pengabdian Masyarakat Universitas Bakrie, yang telah mendanai dan memfasilitasi untuk kegiatan PkM ini.

\section{DAFTAR PUSTAKA}

Akurat.co. (2019). Ekonomi Pengamat: Hampir 70 Persen Pelaku Usaha UMKM Penyandang Disabilitas. Akurat.co. Diakses dari https://akurat.co/ekonomi/id-583687-readpengamat-hampir-70-persen-pelaku-usahaumkm-nbsp-peny andang-disabilitas

Anitasari, N. (2017). Cara Jitu Mengelola Keuangan Usaha Kecil dan Menengah. Zahir. Diakses dari https://zahiraccount ing.com/id/blog/mengelola-keuangan-uk $\mathrm{m} /$ 
Badan Pusat Statistik Provinsi Jawa Barat. (2020). Jumlah Penduduk Menurut Kabupaten/Kota (Jiwa), 2018-2020. Badan Pusat Statistik Provinsi Jawa Barat. Diakses dari https://jabar.bps.go.id/indicator/12/133/1/j umlah-penduduk-menurut-kabupaten-kota. html

Dhairyya, A. P., \& Herawati, E. (2019). Pemberdayaan Sosial dan Ekonomi pada Kelompok Penyandang Disabilitas Fisik di Kota Bandung. Umbara, 4(1), 53-65.

Hikmawati, E. \& Rusmiyati, C. (2011). Kebutuhan Pelayanan Sosial Penyandang Cacat. Informasi, 16(1), 17-32.

John, Van Horn \& John M.W. (2009). PrinsipPrinsip Dasar Manajemen Keuangan. Jakarta: Salemba Empat.

Keumala, C. R. N. (2016). Pengaruh Konsep Desain Universal Terhadap Tingkat Kemandirian Difabel: Studi Kasus Masjid UIN Sunan Kalijaga dan Masjid Universitas Gadjah Mada. INKLUSI, 3(1), 19.
Portal Data Kota Bandung. (2019). Penyandang Disabilitas di Kecamatan Sukajadi Kota Bandung. Portal Data Kota Bandung. Diakses dari http://data.bandung.go.id/dataset/pen yandang-disabilitas-di-kecamatan-sukajadikota-bandung/resourcee/619c21e1-cec14c85-9f16-f8f6c10d6743

Robbins, Stephen P. \& Timothy A. Judge. (2008). Perilaku Organisasi Edisi ke-12. Jakarta: Salemba Empat.

Ross, Westerfield \& Jordan. (2012). The Fundamentals of Corporate Finance. The McGrow Hill Companies Inc.

Undang-Undang Republik Indonesia Nomor 8 Tahun 2016 Penyandang Disabilitas. 15 April 2016. Lembaran Negara Republik Indonesia Tahun 2016 Nomor 69. Jakarta.

Weygandt, J. J., Kimmel, P. D., \& Kieso, D. E. (2010). Financial Accounting, IFRS $4^{\text {th }}$ Edition. New York: John Wiley \& Sons, Inc. 